\title{
Production of crispy bread snacks containing chicken meat and chicken meat powder
}

\author{
HULYA CAKMAK ${ }^{1}$, BURAK ALTINEL ${ }^{2}$, SEHER KUMCUOGLU ${ }^{2}$, DUYGU KISLA ${ }^{2}$ and SEBNEM TAVMAN ${ }^{2}$ \\ ${ }^{1}$ Ege University, Graduate School of Natural and Applied Sciences, Department \\ of Food Engineering, Bornova 35100, Izmir, Turkey \\ ${ }^{2}$ Ege University, Faculty of Engineering, Department of Food Engineering, Bornova 35100, Izmir, Turkey
}

Manuscript received on January 28, 2015; accepted for publication on September 21, 2015

\begin{abstract}
Chicken meat in two different forms (chicken meat and chicken meat powder) were added into white flour and whole wheat blend baguette bread formulations for protein enrichment and finally developing new and healthy snacks. The chicken meat and powder levels were $10 \%$ for white flour baguette, and $15 \%$ for whole wheat blend. The dried baguette samples were packaged under $100 \% \mathrm{~N}_{2}$, and physical, chemical, microbiological and sensorial properties were evaluated during 3 months of storage. Protein content of chicken meat powder added samples were found statistically higher than chicken meat added samples. Hardness of the snacks was significantly affected from type of chicken meat, such as values were higher for chicken meat added samples than chicken meat powder added samples. Lipid oxidation of the snacks was determined by TBA analysis, and TBA value for whole wheat mixture snack with $15 \%$ of chicken meat was the highest among all during storage. The highest overall acceptance score was obtained from white flour snack with $10 \%$ chicken meat. There was no coliform bacteria detected during storage and the results of yeast-mold count and aerobic plate count of snacks remained between the quantitative ranges.
\end{abstract}

Key words: baguette, chicken meat, quality, snack, storage.

\section{INTRODUCTION}

Snack foods usually evoke negative images and recognized as unhealthy with its low nutritional value and high energy density. Deep fried, extruded or baked, but high fat containing snack foods, such as potato chips, doughnuts, popcorn, cookies, crackers, cakes are the biggest offenders of these negative images, however, fruit leathers, nuts, cereal bars are some of the healthier alternatives for appropriate snacking. Food scientists are currently studying in developing and designing

Correspondence to: Sebnem Tavman

E-mail: sebnem.tavman@ege.edu.tr new food products by using enrichment techniques to meet daily macro and micronutrient intake, as well as balancing the energy intake. Especially for prevention of protein malnutrition related diseaseswhich is evident in children-, some researchers have developed snacks either with the addition of functional ingredients to existing formula or creating completely new snacks from these ingredients (Katayama and Wilson 2008, Cho and Rizvi 2010, Erbas 2010, Awoyale et al. 2011, Ktenioudaki et al. 2012, Paraman et al. 2012). In these studies, mostly plant-based protein sources such as okara, lupin seed flour, brewer's (distillers') spent grain were 
used to increase the protein content. But nutritional quality and availability of plant-based proteins are quite low compared to animal-based proteins. Animal-based proteins from eggs, milk, meat and fish are considered as complete proteins because of their favorable balance of essential amino acids. Various alternatives for fortification or enrichment of foods, especially bread have been described in previous studies (Bojňanská et al. 2012, Okafor et al. 2012, Waters et al. 2012, Indrani et al. 2015). Madenci and Bilgiçli (2014) used whey protein concentrate powder and buttermilk powder in leavened and unleavened flat bread dough at different levels $(0,4$ and $8 \%)$. They pointed out that the protein content of the flat breads increased up to $14.6 \%$ with whey protein concentrate powder usage. Significant increments were also observed in ash and mineral $(\mathrm{Ca}, \mathrm{K}, \mathrm{Mg}$ and $\mathrm{P})$ contents of the leavened/unleavened flat bread with utilization of $8 \%$ whey protein concentrate powder or buttermilk powder. Bastos et al. (2014) studied on the effect of fish filleting residues for the enrichment of wheat bread. As a result of the study, they reported that addition of fish processing residue to breads is a possible way to provide essential nutrients to the population through a well-accepted, accessible, and low-cost product. Also food process by-products such as brewer's spent grain can be utilized for bread enrichment with its high level of essential amino acid composition (Waters et al. 2012).

Among these protein sources, chicken meat has a favorable nutritional value; lower in total lipid and higher in total protein content than beef (USDA 2014), as well as lower price compared to the other alternatives. But due to the highly perishable character and short shelf life of the chicken meat, researchers remain distant from this valuable source in the enrichment studies. Cakmak et al. (2013) used chicken meat and chicken meat powder for enrichment of white and whole wheat pan breads. The protein contents of breads were increased up to $18.70 \%$ with maximum level of enrichment. Therefore the authors have been encouraged for increasing the shelf life of these breads by drying.

Drying or dehydration process is described as the removal of the water, which is normally present in foodstuff by applying heat (Brennan 2006). This is a major process in food preservation, because the water activity is as low as no microbiological activity can occur and any deterioration is reduced to a minimum (Toledo 2007). In developing healthy snacks, the drying process is frequently employed to decrease the moisture into less favorable levels for reducing physical, chemical or microbiological deteriorations.

Processing conditions, products nature (moisture content, physicochemical properties etc.), packaging material and storage conditions influence the shelf life of the food products (Galic et al. 2009). Especially degradation in main quality indices of foods might limit the shelf life, and hence the products become unacceptable or harmful to consumer (Sousa-Gallagher et al. 2011). In order to extend the shelf life of foods, either laminated packaging materials are used or deterioration mechanism is delayed by modifying the atmosphere within the package. Modified atmosphere packaging (MAP) removes the natural air of the packaging area and replaces it with an inert gas or special combination of gasses (Emblem 2000, Spencer 2005). With this replacement, product quality of foods will be better, and shelf life will be longer than the previous condition (Ucherek 2001).

The aim of this study was to produce healthy snacks with addition of chicken meat powder and chicken meat for protein enrichment, and determine the physical, chemical, and microbiological quality characteristics of these snacks during three months of storage at room temperature $\left(\sim 25^{\circ} \mathrm{C}\right)$ in a special laminated package. The formulation of the baguette breads was optimized in the previous study of the authors (Cakmak et al. 2013), and this study is 
focused on production of dried protein enriched snacks.

\section{MATERIALS AND METHODS}

\section{MATERIALS}

Commercial white wheat flour type 650 (moisture: $11.94 \%$, protein: $12.13 \%$, on dry basis) and whole wheat flour 650 (moisture: 9.80\%, protein: $10.39 \%$, on dry basis) was obtained from Yuksel Tezcan Gida A.S. (Turkey). The chicken meat powder (CMP) and whole chicken meat (CM) were supplied from Banvit A.S. (Turkey) and Keskinoglu A.S. (Turkey), respectively. EMCE gluten plusP $\mathrm{P}^{\circledR}$ (contents: glucose oxidase, pea protein, wheat flour, anti-caking agent) baking improver (ABP Mühlenchemie A.S., Turkey) were blended with dry ingredients to enhance the bread structure and improve the specific volume. Compressed yeast, salt, spices (tomato powder, red pepper powder, coriander powder, thyme, cumin and black pepper) and virgin olive oil were purchased from a local market in Izmir.

\section{PRODUCTION OF ENRICHED BAGUETTE BREADS}

Chicken meat used in the study was first boiled in tap water until its cold point temperature exceeded $70^{\circ} \mathrm{C}$. Then the skin of whole chicken was removed and the chicken thigh and breast meat was deboned and grounded into small pieces in a blender (Waring Blender, USA). The chicken meat powder (salt free) was kindly supplied by Banvit A.S. (Turkey). This product is a commercially available industrial product mainly used in instant soups and it is produced by auto-claving and drying of deboned and granulated chicken meat according to the information obtained from the supplier.

Baguette bread production was optimized using the traditional French baguette processing (Baardseth et al. 2000) with slight modifications in final proofing period and baking condition. The addition of chicken meat powder and chicken meat
(0-10-15-20-25-30\%) to bread formulations were evaluated by a series of sensory analyses in the previous study of authors (Cakmak et al. 2013). Formulations with $10 \%$ and $15 \%$ enrichments for white flour baguettes and whole wheat blend baguettes respectively, were used for snack production. These baguette breads were flavored with $1 \%$ spice mix $(22.5 \%$ tomato powder, $17.5 \%$ red pepper powder, $17.5 \%$ coriander powder, $15 \%$ thyme, $15 \%$ cumin and $12.5 \%$ black pepper) and $2 \%$ virgin olive oil to increase the general perception of further production of snacks. Formulation of baguette breads was given in Table I. As can be seen in this table, whole wheat flour was mixed with $30 \%(\mathrm{w} / \mathrm{w})$ of white flour to enhance the final texture of baguettes. Also $0.3 \%$ (w/w) EMCE gluten plus $\mathrm{P}^{\circledR}$ baking improver (ABP Mühlenchemie A.S., Turkey) was used in both white flour and whole wheat blend baguette dough formulations. To improve the flavour of the dried snacks, previously blended $1 \%$ spice mix and $2 \%$ virgin olive oil were incorporated into all baguette dough formulations. All the dry ingredients given in Table I -including chicken meat powder or chicken meat- were first mixed and then these mixed ingredients were again mixed with an adequate quantity of water, which was determined according to the farinograph water absorption levels at $500 \mathrm{BU}$, and kneaded in a spiral mixer (ISM-10, Inoksan, Turkey) to get dough of a moderately stiff consistency. The dough was then placed in a fermentation chamber (FGM 100 , Inoksan, Turkey) for $30 \mathrm{~min}$ at $30^{\circ} \mathrm{C}$ and $75 \%$ relative humidity. After manual aeration of the dough for 1 minute, they were divided into $400 \mathrm{~g}$ portions and moulded into baking pans and allowed to rest in the same fermentation chamber for $45 \mathrm{~min}$. Following the final proofing period, the baguettes were baked at the temperature range which was set automatically decreasing from $250^{\circ} \mathrm{C}$ to $220^{\circ} \mathrm{C}$ in a preheated rotary oven (FD-200, Fimak, Turkey) for $15 \mathrm{~min}$ and to avoid dryness of the bread crusts, steam was injected for the first $30 \mathrm{~s}$ of baking. 
TABLE I

Enriched baguette bread formulations.

\begin{tabular}{lcccc}
\hline Ingredients $(\mathrm{g})$ & $\mathrm{T}-10 \mathrm{CMP}$ & $\mathrm{T}-10 \mathrm{CM}$ & $\mathrm{W}-15 \mathrm{CMP}$ & W-15CM \\
\hline White flour & 900 & 900 & 255 & 255 \\
Whole wheat flour & - & - & 595 & 595 \\
Chicken meat powder & 100 & - & 150 & - \\
Chicken meat & - & 100 & - & 150 \\
Yeast & 27.0 & 27.0 & 25.5 & 25.5 \\
Salt & 10.8 & 10.8 & 10.2 & 10.2 \\
Baking improver & 2.70 & 2.70 & 2.55 & 2.55 \\
Spice mix & 9.0 & 9.0 & 8.5 & 8.5 \\
Virgin olive oil & 18 & 18 & 17 & 17 \\
Water* & 680 & 540 & 825 & 605 \\
\hline
\end{tabular}

T; white flour, W; whole wheat flour blend, CMP; chicken meat powder, CM; chicken meat.

*Determined from farinograph at $500 \mathrm{BU}$.

Baguettes were subjected to a 4 hour cooling period at room temperature before drying. All the baguette breads were produced twice ( 30 breads for each production) and the cooled baguettes were stored at $-25^{\circ} \mathrm{C}$ until drying was performed.

\section{DRYING OF SAMPLES AND PACKAGING FOR STORAGE}

Baguette samples from each of the two production batches were rested for two hours at room conditions for thawing. Then all baguettes were sliced into the thickness of $5 \mathrm{~mm}$ with an electric slicer (Bosch Spot, Germany) prior to drying as shown in Figure 1. Samples were dried in a convection oven (Inoksan FBE 010, Turkey) at 170,190 and $210^{\circ} \mathrm{C}$ until the weight remains constant, in order to decide the drying temperature to be applied for snack production for storage trials. Dried baguette slices are shown in Figures 2 and 3. T-10CMP, T-10CM and W-15CMP snacks reached the constant weight at $190^{\circ} \mathrm{C}$ at 22 min of drying, while $\mathrm{W}-15 \mathrm{CM}$ snack reached the constant weight at $28 \mathrm{~min}$. Baguette slices dried at $170^{\circ} \mathrm{C}$ have a harder texture compared to samples dried at higher temperatures because of its longer drying time (34$36 \mathrm{~min}$ ), and baguette slices dried at $210^{\circ} \mathrm{C}$ have darker color compared to other samples as shown

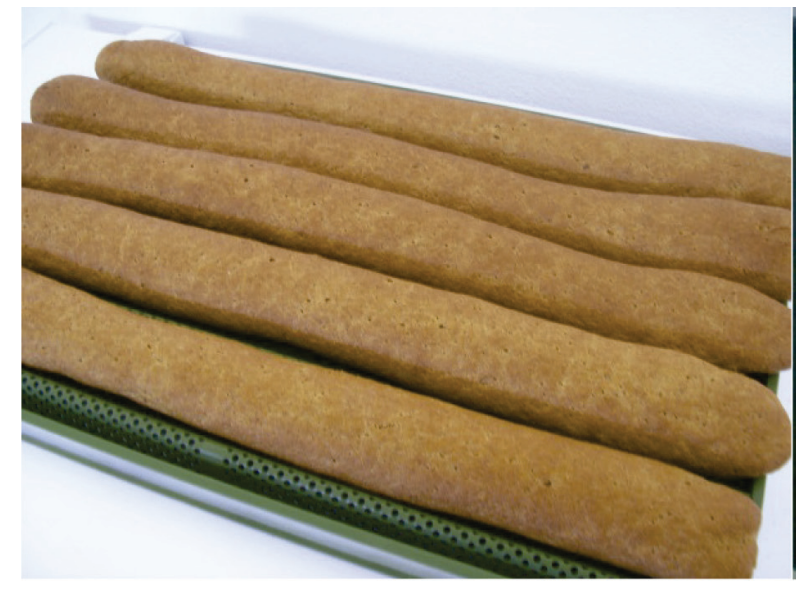

(a)

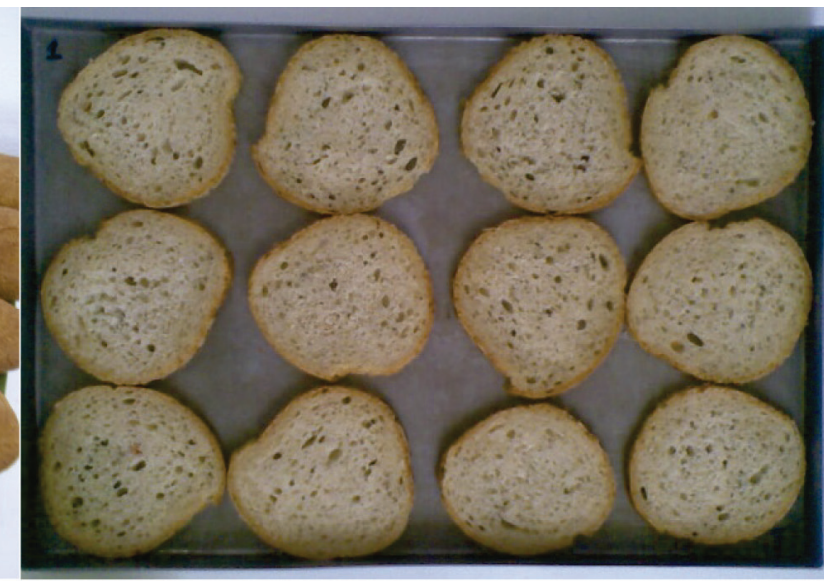

(b)

Figure 1 - Images of baked baguette bread (a), and sliced baguette (b). 
in Figures 2 and 3. Therefore drying temperature of $190^{\circ} \mathrm{C}$ has been selected for snack production. After drying of baguette bread slices, samples were cooled at room temperature and $200 \pm 10 \mathrm{~g}$ of snack packaged under the modified atmospheric conditions $\left(100 \% \mathrm{~N}_{2}\right)$ with a special laminated packaging material to improve light, moisture and oxygen barrier properties for preventing oxidation in snacks as well as protecting snacks against mechanical damages (crushing, breaking etc.). This packaging material has an opaque lacquered PET $(12 \mu)$ on the upper layer, metalized OPP $(20 \mu)$ in the middle layer and PE-EVA-PE (58 $\mu)$ mixture at the inner layer. According to the information given by package manufacturer; the oxygen permeability of the package was $110 \mathrm{cc} / 24 \mathrm{~h} . \mathrm{m}^{2}$.atm (referring to the standard of ASTM D-1434), the nitrogen permeability was $35 \mathrm{cc} / 24 \mathrm{~h} . \mathrm{m}^{2}$.atm (referring to the standard of ASTM D-1434), and the water vapor permeability was $7 \mathrm{~g} / 24 \mathrm{~h} \cdot \mathrm{m}^{2}$ (referring to the standard of ASTM E-96-66), respectively. The packaged snack samples were stored at room temperature $\left(\sim 25^{\circ} \mathrm{C}\right)$ and analyses were carried out for three months with 15 days of intervals.

\section{ANALYSIS OF DRIED ENRICHED BAGUETTE SLICES}

Moisture, protein, ash and fat content of the snacks was determined according to approved methods of AACCI (AACCI 2010a, b, c, e). Water activity was measured with Testo AG400 (Germany) water activity measurement device with a \pm 0.001 sensitivity. The protein, ash and total fat content analysis were only performed on the first day of storage, since those values might change due to the fluctuations in moisture content. Three packed snacks were randomly selected for each snack type, and all analyses were performed at least triplicate and the results were given as the mean value.

Color of snack samples was measured according to Hunter L, a, b color scale using ColorFlex colorimeter (HunterLab, Reston, Virginia, USA) where L is a measure of brightness (0: black, 100: white), $+\mathrm{a} /-\mathrm{a}$ is a measure of redness/ greenness, and $+\mathrm{b} /-\mathrm{b}$ is yellowness/blueness. Total

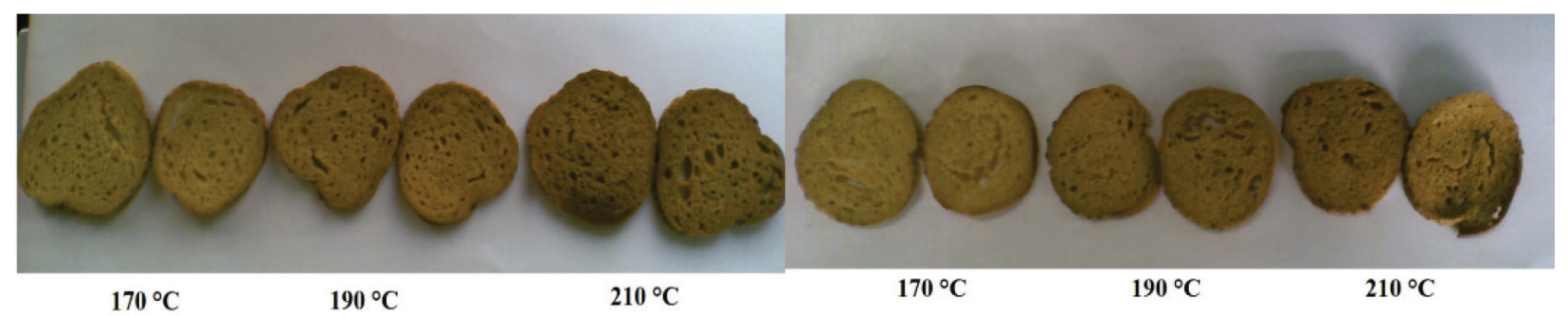

(a)

(b)

Figure 2 - Images of T-10CMP (a), and T-10CM (b) snacks.

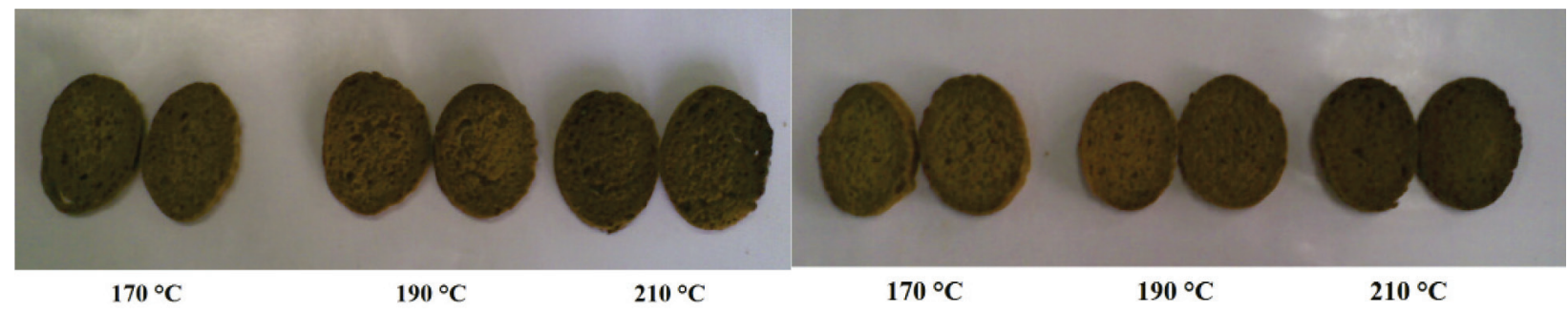

(a)

(b)

Figure 3 - Images of W-15CMP (a), and W-15CM (b) snacks. 
color difference $(\Delta \mathrm{E})$ was calculated according to following formula;

$$
\Delta E=\sqrt{\left[(\Delta L)^{2}+(\Delta a)^{2}+(\Delta b)^{2}\right]}
$$

The $\mathrm{pH}$ of the snacks was analyzed according to approved method of AACCI by using $\mathrm{pH}$ meter (pH537; WTW GmbH, Weilheim, Germany) having \pm 0.01 sensitivity (AACCI 2010d). The snack was manually ground in a mortar and $10 \mathrm{~g}$ of ground sample was put in a $100 \mathrm{ml}$ beaker. The $\mathrm{pH}$ of distilled water was adjusted to $\mathrm{pH} 7$, and this water was added into the beaker containing $10 \mathrm{~g}$ of sample until $100 \mathrm{ml}$, and after continuous stirring for $5 \mathrm{~min}$ the $\mathrm{pH}$ was read.

To measure secondary products of lipid oxidation, TBA (thiobarbituric acid) was determined by using the distillation method of Tarladgis et al. (1960) with the modifications of Ke et al. (1977). The amount of TBA was given as mg malondialdehyde/ $\mathrm{kg}$ sample.

The hardness of the snacks was measured using TA-XT2i texture analyzer (TA-XT2i; Stable Micro Systems Ltd., Surrey, UK) using $30 \mathrm{~kg}$ load cell. Pre-test speed and test speed were $1 \mathrm{~mm} / \mathrm{s}$, while the post-test speed was $10 \mathrm{~mm} / \mathrm{s}$. Threepoint bending test were applied to measure the maximum force $(\mathrm{N})$, which is referred as hardness of the snacks and at least ten different samples was measured.

Aerobic plate count (APC) and yeast-mold count (YMC) were carried out in $0,15,30,60$, 75 and 90 days while coliform bacteria count determined at the beginning and at the end of the storage period as the microbiological analyses of snacks. $10 \mathrm{~g}$ of snack was weighed and transferred into $90 \mathrm{ml}$ of $0.1 \%$ peptone water and homogenized for $1 \mathrm{~min}$ in a stomacher (Seward 400, UK). From $10^{-1}$ dilution, other decimal dilutions were prepared. APC was determined by using pour plate method on plate count agar (PCA; Oxoid, Basingstoke, UK) after incubation at $30^{\circ} \mathrm{C}$ for $48 \mathrm{~h}$ as described by FDA-BAM online (FDA 2001a). YMC was determined by using the spread plate method on acidified ( $\mathrm{pH}$ : 3.5 ) potato dextrose agar (PDA; Oxoid, Basingstoke, UK). Plates were incubated at $25^{\circ} \mathrm{C}$ for 3-5 days and enumerated (FDA 2001b). Coliform bacteria were enumerated by doublelayer pour plate method on violet red bile agar (VRBA, Oxoid, Basingstoke, UK) after incubation at $35^{\circ} \mathrm{C}$ for $18-24 \mathrm{~h}$ (FDA 2002). These analyses were carried out in triplicate.

Sensory analysis for overall acceptance was carried out using 51 randomly selected untrained panelists among the senior and graduate students of Ege University Food Engineering Department for determining the consumer preference of the snacks. Three-point hedonic scale; "-1 being dislike", "0 being neither dislike nor like" and "+1 being like" was used (Altug and Elmaci 2005).

\section{STATISTICAL ANALYSES}

Analysis of variance (ANOVA) was conducted using SPSS 16.0 software (SPSS Inc., USA) and calculated mean values were compared using Duncan post hoc multiple comparison test with a significance level of $99 \%(p<0.01)$ to evaluate the differences between samples. The sensory analysis was evaluated using one-way analysis of variance and Tukey post hoc multiple comparison test with a significance level of $p<0.01$. The results of the microbiological analysis were evaluated using Duncan post hoc multiple comparison test with a significance level of $p<0.05$.

\section{RESULTS AND DISCUSSIONS}

Snack samples were prepared from the baguette breads according to the formulation given in Table I. The snacks were evaluated in all quality aspects including physical, chemical, microbiological and sensorial characteristics for expressing the general structure. These new snacks were developed as an alternative to potato chips, crackers and other highenergy savory snacks. Average protein contents of 
T-10CMP, T-10CM, W-15CMP and W-15CM were found as $18.69,15.47,21.16$, and $17.59 \%$ on dry basis, respectively. Differences between the snacks from CMP and CM could be related to the difference in their compositions and production methods. The amount of chicken meat powder and chicken meat incorporated into baguette bread formulations were same, but the moisture content of CMP $(2.2 \%)$ was quite lower compared to CM (64.64\%). As a result, the protein content of CMP enriched snacks was found higher than CM enriched snacks. Those given protein contents were higher than potato chips, popcorn, rice cakes and corn-based extruded snacks (Table II) (USDA 2014). Average ash contents of T-10CMP, T-10CM, W-15CMP and W-15CM were found as $1.32,1.17,2.09$, and $1.96 \%$ on dry basis, respectively. Ash contents of the samples produced from the whole wheat flour blend were found to be higher than those of white flour used samples. This difference was partially because the ash content of whole wheat flour was higher than white wheat flour as stated in the previous study of Cakmak et al. (2013). Higher ash content in bakery products, which is also an indicator of higher fiber content, is generally suggested for consumption due to their positive effects on health such as decreasing the risk of chronic diseases (diabetes, obesity, heart diseases, etc.). Total fat content of T-10CMP, T-10CM, W-15CMP and W-15CM were $2.66,1.04,3.49$, and $1.93 \%$ on dry basis, respectively. Fat content of snacks produced with CMP was comparably higher than the snacks with $\mathrm{CM}$, and this could be attributed to the production and composition of CMP. Chicken skin was not removed during processing into $\mathrm{CMP}$, and the fat coming from chicken skin, then increased total fat content of the CMP enriched snacks. Regular potato chips, popcorn, corn-based extruded snacks, reduced fat potato chips, and even plain rice cakes produced from brown rice had higher fat contents than the chicken meat powder and chicken meat enriched snacks (USDA 2014).

Moisture content and water activity values of the samples during storage were given in Table III and Figure 4. Initial and final moisture contents of the samples were between 2.927 and $8.280 \%$, while at the end of storage they were between 3.608 and $7.537 \%$. The water activity of the samples was between 0.117 and 0.497 . The lowest values were found for $\mathrm{T}-10 \mathrm{CM}$ and the highest values were found for W-15CM. As it was stated in the study of Ktenioudaki et al. (2012), physical changes started to occur when water activity is between 0.35 to 0.50 . Only $\mathrm{W}-15 \mathrm{CM}$ within these limits, but those values were still unfavorable for microbial growth as can be seen in the microbiological analyses.

In snack foods, the main deterioration mechanisms are moisture uptake and oxidation,

TABLE II

Nutritional composition of the snacks.

\begin{tabular}{lcccc}
\hline Snack & Protein $(\%)^{*}$ & Fat $(\%)^{*}$ & Moisture (\%) & Reference \\
\hline Potato chips, plain & 6.51 & 34.62 & 1.86 & USDA 2014 \\
Popcorn, air popped & 12.51 & 4.38 & 4.10 & USDA 2014 \\
Corn-based extruded chips, plain & 6.24 & 33.72 & 1.07 & USDA 2014 \\
Reduced fat potato chips & 7.17 & 21.01 & 1.00 & USDA 2014 \\
Rice cake, brown rice plain & 8.71 & 2.97 & 5.80 & USDA 2014 \\
T-10CMP & 18.69 & 2.66 & 4.10 & This study \\
T-10CM & 15.47 & 1.04 & 2.93 & This study \\
W-15CMP & 21.16 & 3.49 & 5.81 & This study \\
W-15CM & 17.59 & 1.93 & 8.28 & This study \\
\hline
\end{tabular}

*dry basis. 
which causes loss of crispiness and creates rancid flavor (Kilcast and Subramaniam 2000), so determining the change in moisture and TBA has crucial importance for the final quality of the snacks. Amount of TBA is an indicator of lipid oxidation and it is found to be remained almost constant during 90 days storage as seen in Figure 5. The fat content of $\mathrm{W}-15 \mathrm{CMP}$ was the highest; however, the TBA value of W-15CM snack was the highest among all during storage. This could be due to long exposure time during drying at $190^{\circ} \mathrm{C}$ of $\mathrm{W}-15 \mathrm{CM}$ (28 $\mathrm{min}$ ) than the other snacks (22 min). There was no rancid flavor detected by sensory panelists of this present study, as the threshold value for rancidity in meat was reported as 1-2 mg malondialdehyde/kg (Alkass et al. 2013).

$\mathrm{pH}$ values are given in Table III. The values for each sample were decreased during storage and were between 5.840-6.050 at the beginning of storage and between 5.480 and 5.780 at the end of storage. The final $\mathrm{pH}$ values were found to be lower than the initial values for all snacks depending on the storage time, but no significant difference was observed between almost all the snack types.

Hardness of the snacks was measured during 90 days, and the results are presented in Table IV.
The samples had a similar tendency during storage; however, the hardness of T-10CMP decreased significantly during this period $(p<0.01)$. Initial hardness value of W-15CMP was significantly the lowest among all $(p<0.01)$, while the final values for T-10 CMP hardness was the lowest $(p<0.01)$. W-15CM snack was comparably higher hardness values, depending on the denser structure of baguette bread before drying. So, all in all, the hardness values at the 45th and 60th days of the storage were higher than those other storage intervals. Hardness values of the snacks, even hardness of W-15CM, was quite lower compared to breadsticks given in the study of Ktenioudaki et al. (2012), and also the change of hardness during storage found to have similar tendency. In this study brewer's spent grain (BSG) was used at different percentages as a functional ingredient in breadsticks. Although BSG addition significantly increased protein contents, it was found that BSG addition affected baking characteristics such as structure and texture. During storage period the change in hardness of the snacks in our study had similarly

Total color difference $(\Delta \mathrm{E})$ was calculated by taking the initial values (day 0 ) as a control of each

TABLE III

Moisture and pH of the snacks.

\begin{tabular}{|c|c|c|c|c|c|c|c|c|}
\hline \multicolumn{5}{|c|}{ Moisture (\%) } & \multicolumn{4}{|c|}{ pH } \\
\hline $\begin{array}{l}\text { Storage period } \\
\text { (days) }\end{array}$ & T-10CMP & $\mathrm{T}-10 \mathrm{CM}$ & W-15CMP & W-15CM & T-10CMP & $\mathrm{T}-10 \mathrm{CM}$ & W-15CMP & W-15CM \\
\hline 0 & $4.095^{\mathrm{c}, \mathrm{B}}$ & $2.927^{\mathrm{b}, \mathrm{A}}$ & $5.813^{\mathrm{d}, \mathrm{C}}$ & $8.280^{\mathrm{e}, \mathrm{D}}$ & $5.88^{\mathrm{d}, \mathrm{A}}$ & $5.84^{\mathrm{e}, \mathrm{A}}$ & $5.90^{\mathrm{c}, \mathrm{A}}$ & $6.05^{\mathrm{d}, \mathrm{B}}$ \\
\hline 15 & $4.293^{\mathrm{d}, \mathrm{B}}$ & $3.153^{\mathrm{c}, \mathrm{A}}$ & $5.793^{\mathrm{d}, \mathrm{C}}$ & $7.197^{\mathrm{a}, \mathrm{D}}$ & $5.85^{\mathrm{d}, \mathrm{A}, \mathrm{B}}$ & $5.79^{\mathrm{d}, \mathrm{A}}$ & $5.93^{\mathrm{c}, \mathrm{d}, \mathrm{B}, \mathrm{C}}$ & $5.99^{\mathrm{c}, \mathrm{C}}$ \\
\hline 30 & $4.258^{\mathrm{d}, \mathrm{B}}$ & $3.299^{\mathrm{d}, \mathrm{A}}$ & $5.370^{\mathrm{c}, \mathrm{C}}$ & $7.521^{\mathrm{b}, \mathrm{D}}$ & $5.97^{\mathrm{e}, \mathrm{A}}$ & $5.92^{\mathrm{f}, \mathrm{A}}$ & $5.96^{\mathrm{d}, \mathrm{A}}$ & $6.11^{\mathrm{e}, \mathrm{B}}$ \\
\hline 45 & $3.808^{\mathrm{a}, \mathrm{B}}$ & $2.761^{\mathrm{a}, \mathrm{A}}$ & $4.574^{\mathrm{a}, \mathrm{C}}$ & $7.835^{\mathrm{c}, \mathrm{D}}$ & $5.39^{\mathrm{a}, \mathrm{A}}$ & $5.36^{\mathrm{a}, \mathrm{A}}$ & $5.51^{\mathrm{a}, \mathrm{B}}$ & $5.65^{\mathrm{a}, \mathrm{C}}$ \\
\hline 60 & $4.143^{\mathrm{c}, \mathrm{B}}$ & $2.915^{\mathrm{b}, \mathrm{A}}$ & $4.846^{\mathrm{b}, \mathrm{C}}$ & $8.147^{\mathrm{d}, \mathrm{D}}$ & $5.42^{\mathrm{a}, \mathrm{B}}$ & $5.34^{\mathrm{a}, \mathrm{A}}$ & $5.53^{\mathrm{a}, \mathrm{C}}$ & $5.69^{\mathrm{a}, \mathrm{D}}$ \\
\hline 75 & $4.415^{\mathrm{c}, \mathrm{B}}$ & $3.335^{\mathrm{d}, \mathrm{A}}$ & $6.116^{\mathrm{e}, \mathrm{C}}$ & $8.168^{f, D}$ & $5.76^{\mathrm{c}, \mathrm{B}}$ & $5.69^{\mathrm{c}, \mathrm{A}}$ & $5.90^{\mathrm{c}, \mathrm{C}}$ & $6.01^{\mathrm{c}, \mathrm{d}, \mathrm{D}}$ \\
\hline 90 & $3.994^{\mathrm{b}, \mathrm{B}}$ & $3.608^{\mathrm{e}, \mathrm{A}}$ & $5.077^{\mathrm{b}, \mathrm{C}}$ & $7.537^{\mathrm{b}, \mathrm{D}}$ & $5.52^{\mathrm{b}, \mathrm{A}}$ & $5.49^{\mathrm{b}, \mathrm{A}}$ & $5.65^{\mathrm{b}, \mathrm{B}}$ & $5.78^{\mathrm{b}, \mathrm{C}}$ \\
\hline
\end{tabular}

T-10CMP: $10 \%$ chicken meat powder enriched white flour baguette snack, T-10CM: 10\% chicken meat enriched white flour baguette snack, W-15CMP: $15 \%$ chicken meat powder enriched whole wheat blend baguette snack, W-15CM: $15 \%$ chicken meat enriched whole wheat blend baguette snack.

${ }^{\mathrm{a}-\mathrm{f}}$ Mean values with different superscripts in the same column are significantly different $(p<0.01)$.

${ }^{A-D}$ Mean values with different superscripts in the same row are significantly different $(p<0.01)$. 


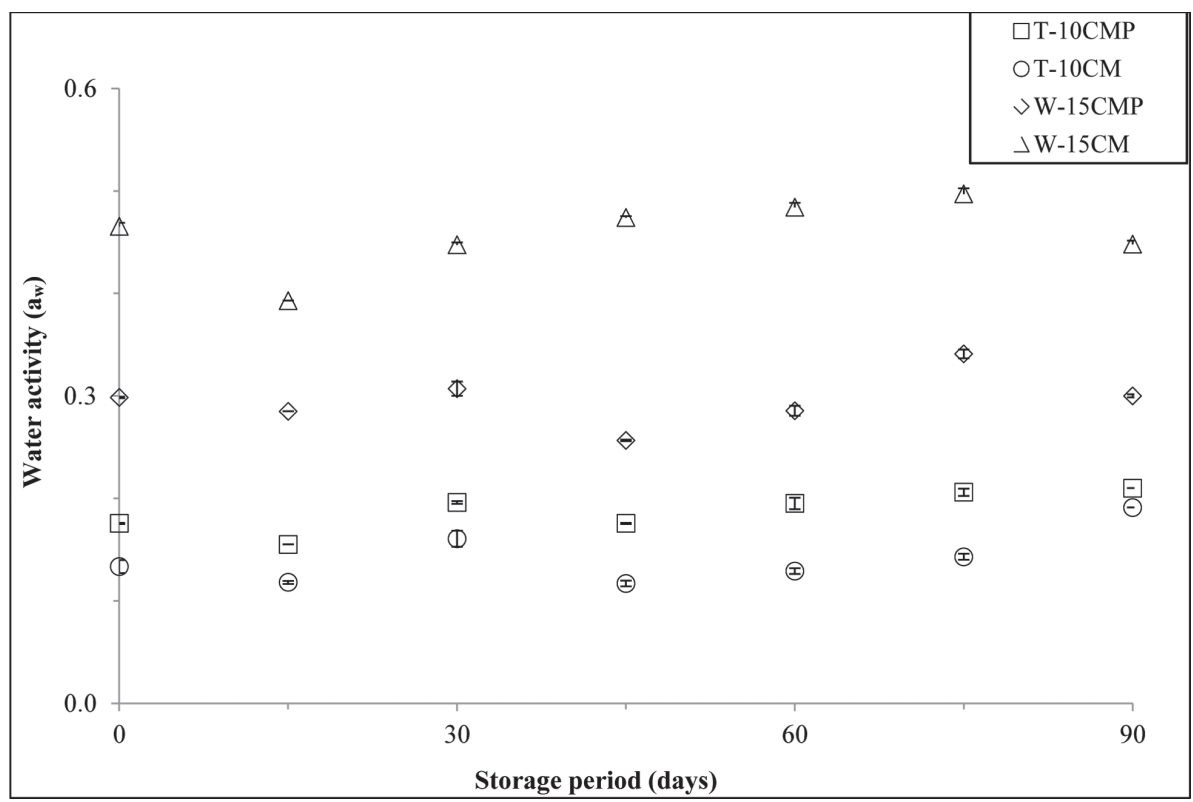

Figure 4 - Water activity values of enriched snacks.

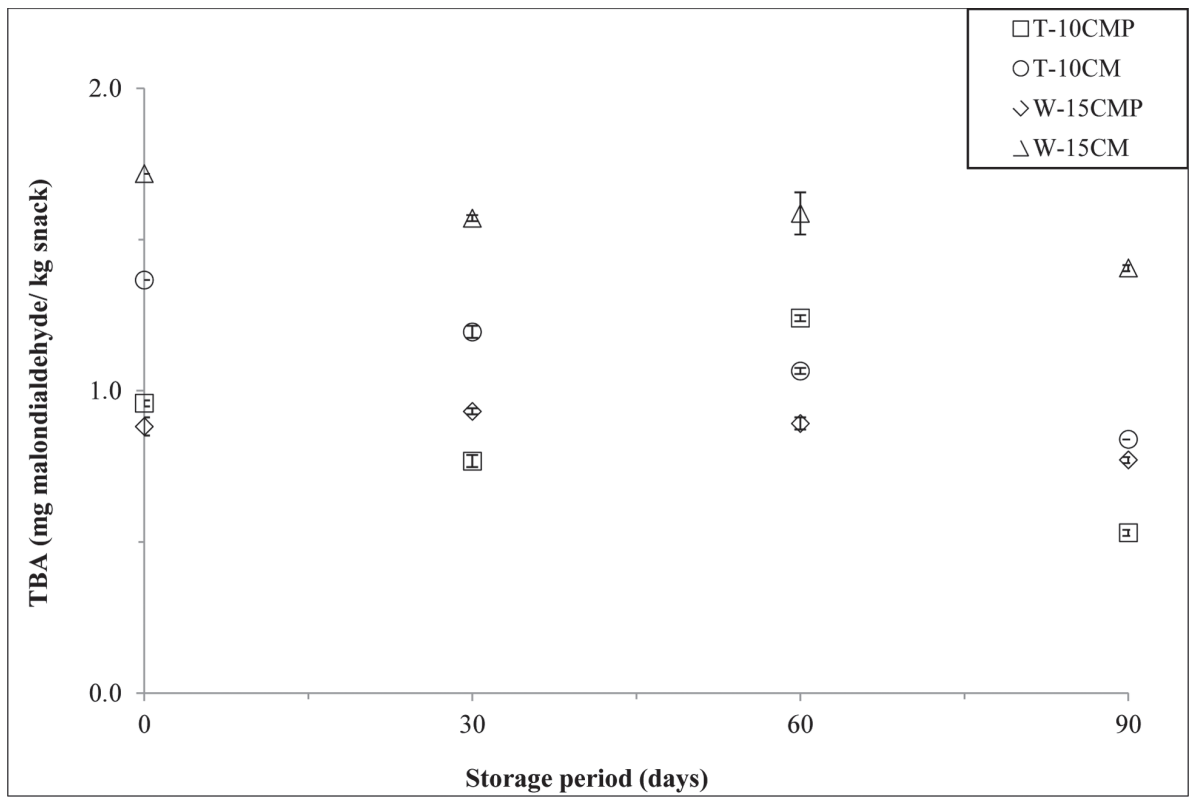

Figure 5 - TBA values of enriched snacks.

sample and they are shown in Table IV. The values were increased significantly $(p<0.01)$ during 90 days, except $\mathrm{T}-10 \mathrm{CM}$ which was remained unchanged. The whiteness values for each sample did not differ significantly ( $p>0.01)$, but the redness and yellowness values changed significantly (results were not shown). W-15CMP sample had comparably higher $\Delta \mathrm{E}$ values than the rest of the snacks during whole storage period.

Evaluation of sensorial acceptance in pilot scale, minimum of 50 panelists is recommended (Kilcast and Subramaniam 2000, Altug and Elmaci 2005). According to the results of the hedonic test, the highest overall acceptance score was found for 
TABLE IV

Hardness and total color difference of the snacks.

\begin{tabular}{|c|c|c|c|c|c|c|c|c|}
\hline \multicolumn{5}{|c|}{ Hardness (N) } & \multicolumn{4}{|c|}{$\Delta \mathbf{E}$ (total color difference) } \\
\hline $\begin{array}{c}\text { Storage period } \\
\text { (days) }\end{array}$ & T-10CMP & $\mathrm{T}-10 \mathrm{CM}$ & W-15CMP & W-15CM & T-10CMP & $\mathrm{T}-10 \mathrm{CM}$ & W-15CMP & $\mathrm{W}-15 \mathrm{CM}$ \\
\hline 0 & $9.297^{\mathrm{c}, \mathrm{C}}$ & $8.195^{\mathrm{b}, \mathrm{B}}$ & $5.772^{\mathrm{a}, \mathrm{A}}$ & $8.367^{\mathrm{a}, \mathrm{B}}$ & - & - & - & - \\
\hline 15 & $7.489^{\mathrm{a}, \mathrm{b}, \mathrm{A}}$ & $7.593^{\mathrm{b}, \mathrm{A}}$ & $7.858^{\mathrm{b}, \mathrm{A}}$ & $7.628^{\mathrm{a}, \mathrm{A}}$ & $1.952^{\mathrm{b}, \mathrm{C}}$ & $1.550^{\mathrm{b}, \mathrm{A}}$ & $2.970^{\mathrm{c}, \mathrm{D}}$ & $1.700^{\mathrm{b}, \mathrm{B}}$ \\
\hline 30 & $7.886^{\mathrm{b}, \mathrm{A}}$ & $7.401^{\mathrm{b}, \mathrm{A}}$ & $7.724^{\mathrm{b}, \mathrm{A}}$ & $17.341^{\mathrm{c}, \mathrm{B}}$ & $3.210^{\mathrm{c}, \mathrm{D}}$ & $2.885^{\mathrm{d}, \mathrm{C}}$ & $1.898^{\mathrm{a}, \mathrm{B}}$ & $1.150^{\mathrm{a}, \mathrm{A}}$ \\
\hline 45 & $11.351^{\mathrm{d}, \mathrm{A}}$ & $13.913^{\mathrm{d}, \mathrm{A}}$ & $13.818^{\mathrm{d}, \mathrm{A}}$ & $20.820^{\mathrm{d}, \mathrm{B}}$ & $2.035^{\mathrm{b}, \mathrm{C}}$ & $1.295^{\mathrm{a}, \mathrm{B}}$ & $3.483^{\mathrm{d}, \mathrm{D}}$ & $1.118^{\mathrm{a}, \mathrm{A}}$ \\
\hline 60 & $11.670^{\mathrm{d}, \mathrm{A}}$ & $10.070^{\mathrm{c}, \mathrm{A}}$ & $11.850^{\mathrm{c}, \mathrm{A}}$ & $24.354^{\mathrm{e}, \mathrm{B}}$ & $3.320^{\mathrm{d}, \mathrm{D}}$ & $2.130^{\mathrm{c}, \mathrm{B}}$ & $2.005^{\mathrm{a}, \mathrm{A}}$ & $2.598^{\mathrm{c}, \mathrm{C}}$ \\
\hline 75 & $7.112^{\mathrm{a}, \mathrm{b}, \mathrm{A}}$ & $5.495^{\mathrm{a}, \mathrm{A}}$ & $10.627^{\mathrm{c}, \mathrm{B}}$ & $11.935^{\mathrm{b}, \mathrm{B}}$ & $1.458^{\mathrm{a}, \mathrm{B}}$ & $1.303^{\mathrm{a}, \mathrm{A}}$ & $2.583^{\mathrm{b}, \mathrm{C}}$ & $2.938^{\mathrm{d}, \mathrm{D}}$ \\
\hline 90 & $6.776^{\mathrm{a}, \mathrm{A}}$ & $7.926^{\mathrm{b}, \mathrm{A}}$ & $7.923^{\mathrm{b}, \mathrm{A}}$ & $12.822^{\mathrm{b}, \mathrm{B}}$ & $4.430^{\mathrm{e}, \mathrm{B}}$ & $1.543^{\mathrm{b}, \mathrm{A}}$ & $6.628^{\mathrm{e}, \mathrm{D}}$ & $5.650^{\mathrm{e}, \mathrm{C}}$ \\
\hline
\end{tabular}

T-10CMP: 10\% chicken meat powder enriched white flour baguette snack, T-10CM: 10\% chicken meat enriched white flour baguette snack, W-15CMP: $15 \%$ chicken meat powder enriched whole wheat blend baguette snack, W-15CM: $15 \%$ chicken meat enriched whole wheat blend baguette snack.

${ }^{a-e}$ Mean values with different superscripts in the same column are significantly different $(p<0.01)$.

${ }^{A-D}$ Mean values with different superscripts in the same row are significantly different $(p<0.01)$.

T-10CM, however the lowest score was obtained for $\mathrm{W}-15 \mathrm{CM}(p<0.01)$. The average scores of the snacks were $-0.06,0.47,-0.39$ and -0.61 for T-10CMP, T-10CM, W-15CMP and W-15CM, respectively. Also all the scores were found statistically different from each other $(p<0.01)$. The lower scores for the whole wheat blend snacks could be related with the consumer preferences and daily eating habits. The daily carbohydrate consumptions of young people are unfortunately still based on white flour bakery products.

The results of microbiological analyses of snacks are shown in Table V and VI. No significant differences were observed between the APCs of the snacks at the beginning and at the end of the storage $(p>0.05)$, except the counts of W-15CM. The lowest APC was found in each group of snacks at day 60 during the storage period and the lowest APC was observed in W-15CM on each storage day except 90 days of storage. There were significant differences in the APCs of snacks at 0, 15, 30 and 75 days of the storage period $(p<0.05)$ while no significant differences were found in the counts of snacks at 60 ad 90 days of storage $(p>0.05)$.

No significant differences were observed in YMCs of snacks during the storage period $(p>0.05)$ except the counts of T-10CM. However, there were significant differences in the YMCs of snacks at the beginning, 15, 30 and 90 days of storage $(p<0.05)$, whereas the differences in the counts at day 60 and 75 days of storage were not statistically significant $(p>0.05)$.

No coliform bacteria were detected in the snacks both at the beginning (day 0 ) and at the end of the storage (day 90).

The main purpose of reducing water activity in food is to prevent or reduce the growth of vegetative cells and germination and outgrowth of spores of microorganisms. As water activity drops below 0.6, microbial growth stops (Gould 2000). The water activity values of cereals, crackers, sugar, salt, dry milk are approximately $0.10-0.20$ while these values are less than 0.60 for noodles, honey, chocolate, dried egg (Ray and Bhunia 2013). The water activity values of the samples in the present study ranged from 0.117 to 0.497 , these values remained at the levels which are insufficient for microbial growth during the storage period.

In the study of Hozová et al. (1995), microbiological evaluation of the amaranthbased snacks (water activity 0.38 ) made of wheat flour, amaranth flour, sugar, fat, eggs, aromatic 
TABLE V

Changes in $\mathrm{APCs}^{1}$ (log cfu/g) of snacks during storage period.

\begin{tabular}{ccccccc}
\hline \multicolumn{7}{c}{ Storage period (days) } \\
\hline T-10CMP & 0 & 15 & 30 & 60 & 75 & 90 \\
T-10CM & $2.61 \pm 0.07^{\mathrm{b}, \mathrm{C}}$ & $2.95 \pm 0.06^{\mathrm{b}, \mathrm{B}}$ & $3.03 \pm 0.29^{\mathrm{b}, \mathrm{B}}$ & $1.85 \pm 0.85^{\mathrm{a}, \mathrm{A}}$ & $2.98 \pm 0.03^{\mathrm{b}, \mathrm{B}}$ & $2.94 \pm 0.40^{\mathrm{b}, \mathrm{A}}$ \\
W-15CMP & $2.63 \pm 0.20^{\mathrm{a}, \mathrm{C}}$ & $2.95 \pm 0.32^{\mathrm{a}, \mathrm{B}}$ & $2.61 \pm 0.06^{\mathrm{a}, \mathrm{B}}$ & $2.32 \pm 0.44^{\mathrm{a}, \mathrm{A}}$ & $2.77 \pm 0.00^{\mathrm{a}, \mathrm{B}}$ & $2.79 \pm 0.22^{\mathrm{a}, \mathrm{A}}$ \\
W-15CM & $2.08 \pm 0.09^{\mathrm{b}, \mathrm{B}}$ & $2.43 \pm 0.08^{\mathrm{b}, \mathrm{A}}$ & $2.82 \pm 0.15^{\mathrm{c}, \mathrm{B}}$ & $1.90 \pm 0.20^{\mathrm{a}, \mathrm{A}}$ & $2.42 \pm 0.02^{\mathrm{b}, \mathrm{A}}$ & $2.33 \pm 0.31^{\mathrm{b}, \mathrm{A}}$ \\
\hline
\end{tabular}

${ }^{1}$ : Each value is the arithmetic mean \pm standard deviation of three samples.

${ }^{a-c}$ Mean values with different superscripts in the same row are significantly different $(p<0.05)$.

${ }^{\text {A-C }}$ Mean values with different superscripts in the same column are significantly different $(p<0.05)$.

TABLE VI

Changes in $\mathrm{YMCs}^{1}(\log \mathrm{cfu} / \mathrm{g})$ of snacks during storage period.

\begin{tabular}{ccccccc}
\hline \multicolumn{7}{c}{ Storage period (days) } \\
\hline T-10CMP & 0 & 15 & 30 & 60 & 75 & 90 \\
T-10CM & $2.80 \pm 0.10^{\mathrm{a}, \mathrm{C}}$ & $3.05 \pm 0.05^{\mathrm{a}, \mathrm{C}}$ & $3.06 \pm 0.11^{\mathrm{a}, \mathrm{C}}$ & $2.96 \pm 0.36^{\mathrm{a}, \mathrm{A}}$ & $3.05 \pm 0.15^{\mathrm{a}, \mathrm{A}}$ & $2.87 \pm 0.47^{\mathrm{a}, \mathrm{BC}}$ \\
$\mathrm{W}-15 \mathrm{CMP}$ & $2.50 \pm 0.17^{\mathrm{ab}, \mathrm{C}}$ & $3.17 \pm 0,15^{\mathrm{b}, \mathrm{C}}$ & $2.65 \pm 0.05^{\mathrm{a}, \mathrm{B}}$ & $3.09 \pm 0.35^{\mathrm{b}, \mathrm{A}}$ & $2.96 \pm 0.05^{\mathrm{ab}, \mathrm{A}}$ & $2.98 \pm 0.08^{\mathrm{ab}, \mathrm{C}}$ \\
$\mathrm{W}-15 \mathrm{CM}$ & $2.68 \pm 0.14^{\mathrm{a}, \mathrm{B}}$ & $2.70 \pm 0.05^{\mathrm{a}, \mathrm{B}}$ & $2.78 \pm 0.48^{\mathrm{a}, \mathrm{A}}$ & $2.57 \pm 0.17^{\mathrm{a}, \mathrm{A}}$ & $2.40 \pm 0.01^{\mathrm{a}, \mathrm{A}}$ \\
\hline
\end{tabular}

${ }^{1}$ : Each value is the arithmetic mean \pm standard deviation of three samples.

${ }^{a-b}$ Mean values with different superscripts in the same row are significantly different $(p<0.05)$.

${ }^{\text {A-C }}$ Mean values with different superscripts in the same column are significantly different $(p<0.05)$.

ingredients were performed. No coliform bacteria, yeasts and molds ascertained in the products, but APC was found to be $1.4 \times 10^{3} / \mathrm{g}$ in the sixth month of storage. Our results for APC almost complied with the results of the aforementioned authors' study. There is no specific regulation for chicken snacks in Turkish legislation. However, according to the microbial criteria in Regulation on Turkish Food Codex Microbiological Criteria (Anonymous 2011), for breakfast cereals, whole grain products, muesli, cornflakes, chips etc. grain-based products, coliform bacteria count and YMC must not exceed $10^{3} / \mathrm{g}$ and $10^{4} / \mathrm{g}$, respectively. Quantitative ranges of molds, yeasts, APC, coliform bacteria were stated as $<1-10^{3} / \mathrm{g},<1-10^{2} / \mathrm{g},<1-10^{2} / \mathrm{g},<1-10^{2} / \mathrm{g}$, respectively for the breakfast cereals and snack foods (Downes and Ito 2001). Ray and Bhunia (2013) stated in their study that breakfast cereals and pasta might contain APC of $10^{2-3} / \mathrm{g}$, coliform of $<10^{1-2} / \mathrm{g}$, and yeasts and molds of $<10^{1-2} / \mathrm{g}$.
Considering the criteria in the literatures mentioned above, microbial counts of snacks in the present study remained between the quantitative ranges during the storage period.

\section{CONCLUSIONS}

Depending on the results of the tested quality parameters (physical, chemical, sensorial and microbial analysis), newly developed snacks have shown promising results. These snacks were higher in protein and ash content and lower in total fat content compared to the most popular snack alternatives such as; potato chips, crackers and other commercially available high-energy savory snacks. Chicken meat powder and chicken meat having a favorable nutritional value; lower total lipid and higher protein content make these snacks more nutritious; however further studies can be done to improve sensorial properties of the snacks. 


\section{ACKNOWLEDGMENTS}

This research was funded by The Scientific and Technological Research Council of Turkey (TUBITAK) with project no: 110-O-030 and Ege University Scientific Research Project Commission (BAP) with project no: 11-MUH-027.

\section{REFERENCES}

AACCI. 2010a. Approved Methods of Analysis, Crude Protein-Kjeldahl Method, Boric Acid Modification. AACCI International, St. Paul, MN.

AACCI. 2010b. Approved Methods of Analysis, Ash-Basic Method. AACCI International, St. Paul, MN.

AACCI. 2010c. Approved Methods of Analysis, Calculation of Percent Moisture. AACCI International, St. Paul, MN.

AACCI. 2010d. Approved Methods of Analysis, HydrogenIon Activity (pH)- Electrometric Method. AACCI International, St. Paul, MN.

AACCI. 2010e. Approved Methods of Analysis, Crude Fat in Flour, Bread, and Baked Cereal Products Not Containing Fruit. AACCI International, St. Paul, MN.

ALKASS JE, BAKER IA AND SALEH HH. 2013. Reduction of oxidative rancidity and microbial activities of the Karadi lamb patties in freezing storage using natural antioxidant extracts of rosemary and ginger. International Journal of Agricultural and Food Research 2(1): 31-42.

ALTUG T AND ELMACI Y. 2005. Gidalarda duyusal degerlendirme, $1^{\text {st }}$ ed., Izmir: Meta Basim, $130 \mathrm{p}$.

ANONYMOUS. 2011. Regulation on Turkish food codex microbiological criteria. Republic of Turkey ministry of food, agriculture and livestock, Official gazette of publication, No: 28157, http://www.resmigazete.gov. tr/eskiler/2011/12/20111229M3-6.htm (Access date: 11.11.2014).

AWOYALE W, MAZIYA-DIXON B, SANNI LO AND SHITTU TA. 2011. Nutritional and sensory properties of a maize-based snack food (kokoro) supplemented with treated Distillers' spent grain (DSG). Int J Food Sci Tech 46: 1609-1620.

BAARDSETH P, KVAAL K, LEA P, ELLEKJAER MR AND FAERGESTAD EM. 2000. The effects of bread making process and wheat quality on French baguettes. $\mathrm{J}$ Cereal Sci 32: 73-87.

BASTOS SC, TAVARES T, PIMENTA MEDSG, LEAL R, FABRÍCIO LF, PIMENTA CJ, NUNES CA AND PINHEIRO ACM. 2014. Fish filleting residues for enrichment of wheat bread: chemical and sensory characteristics. J Food Sci Technol 51(9): 2240-2245.

BOJŇANSKÁ T, FRANČÁKOVÁ H, LIŠKOVÁ M AND TOKÁR M. 2012. Legumes - The alternative raw materials for bread production. J Microbiol Biotechnol Food Sci (February Special issue), p. 876-886.

BRENNAN JG. 2006. Evaporation and dehydration. In: Brennan JG (Ed), Food processing handbook, Weinheim: Wiley-VCH Verlag GmbH \& Co., Weinheim, Germany, p. 71-124.

CAKMAK H, ALTINEL B, KUMCUOGLU S AND TAVMAN S. 2013. Chicken meat added bread formulation for protein enrichment. Food Feed Res 40: 33-41.

CHO KY AND RIZVI SSH. 2010. New generation of healthy snack food by supercritical fluid extrusion. J Food Process Pres 34: 192-218.

DOWNES FP AND ITO K. 2001. Compendium of methods for the microbiological examination of foods, $4^{\text {th }} \mathrm{ed}$., Washington: American Public Health Association, 676 p.

EMBLEM A. 2000. Predicting packaging characteristics to improve shelf life. In: Kilcast D and Subramaniam P (Eds), Food and beverage stability and shelf life, Cambridge: Woodhead Publishing Limited, Cambridge, UK, p. 145-169.

ERBAS M. 2010. The effects of different debittering methods on the production of lupin bean snack from bitter Lupinus albus L. seeds. J Food Quality 33: 742-757.

FDA. 2001a. Bacteriological Analytical Manual, Aerobic Plate Count. Silver Spring: FDA.

FDA. 2001b. Bacteriological analytical manual, yeasts, molds and mycotoxins. Silver Spring: FDA.

FDA. 2002. Bacteriological analytical manual, enumeration of Escherichia coli and the coliform bacteria, Silver Spring: FDA.

GALIC K, CURIC D AND GABRIC D. 2009. Shelf life of packaged bakery goods, a review. Crc Cr Rev Food Sci 49: 405-426.

GOULD GW. 2000. Preservation: past, present and future. Brit Med Bull 56: 84-96.

HOZOVÁ B, ZEMANOVIČ J AND CHORVÁTOVÁ R. 1995. Evaluation of the microbiological and sensory quality of amaranth-based biscuits. Food Technol Biotech 33(4): 155-159.

INDRANI D, SAKHARE SD, INAMDAR AA AND RAO GV. 2015. Development of protein and fiber enriched breads by supplementation of roller milled fractions of green gram. J Food Sci Technol 52(1): 415-422.

KATAYAMA M AND WILSON LA. 2008. Utilization of okara, a byproduct from soymilk production, through the development of soy-based snack food. J Food Sci 73(3): 152-157.

KE PJ, ACKMAN RG, LINKE BA AND NASH DM. 1977. Differential lipid oxidation in various parts of frozen mackerel. Int J Food Sci Tech 12: 37-47.

KILCAST D AND SUBRAMANIAM P. 2000. The stability and shelf-life of food, Cambridge: Woodhead Publishing Limited, 849 p.

KTENIOUDAKI A, CHAURIN V, REIS SF AND GALLAGHER E. 2012. Brewer's spent grain as a 
functional ingredient for breadsticks. Int J Food Sci Tech 47: 1765-1771.

MADENCI AB AND BILGIÇLI N. 2014. Effect of whey protein concentrate and buttermilk powders on rheological properties of dough and bread quality. J Food Quality 37: 117-124.

OKAFOR JNC, OKAFOR GI, OZUMBA AU AND ELEMO GN. 2012. Quality characteristics of bread made from wheat and nigerian oyster mushroom (Pleurotus plumonarius) powder. Pakistan J Nutrition 11(1): 5-10.

PARAMAN I, WAGNER ME AND RIZVI SSH. 2012. Micronutrient and protein-fortified whole grain puffed rice made by supercritical fluid extrusion. J Agr Food Chem 60: 11188-11194.

RAY B AND BHUNIA A. 2013. Fundamental food microbiology, $5^{\text {th }}$ ed., Boca Raton: CRC press, $663 \mathrm{p}$.

SOUSA-GALLAGHER MJ, MAHAJAN PV AND YAN Z. 2011. Modelling chemical and physical deterioration of foods and beverages. In: Kilcast D and Subramaniam P (Eds), Food and beverage stability and shelf life, Cambridge: Woodhead Publishing Limited, Cambridge, UK, p. 459-481.
SPENCER KC. 2005. Modified atmosphere packaging of ready-to-eat foods. In: Han JH (Ed), Innovations in Food Packaging, Oxford: Elsevier Science, Oxford, UK, p. 185203.

TARLADGIS B, WATTS B, YOUNATHAN M AND DUGAN Jr L. 1960. A distillation method for the quantitative determination of malonaldehyde in rancid foods. J Am Oil Chem Soc 37: 44-48.

TOLEDO RT. 2007. Dehydration. In: Toledo RT (Ed), Fundamentals in food process engineering, New York: Springer, New York, USA, p. 431-473.

UCHEREK M. 2001. The interrelation of changes content and product quality in oxygen in modified atmosphere packages of peanuts. Packag Technol Sci 14: 249-252.

USDA. 2014. National nutrient database for standard reference. USDA, Nutrient Data Laboratory Home Page, http://ndb. nal.usda.gov/ndb/search/list (Access date: 12.08.2014).

WATERS DM, JACOB F, TITZE J, ARENDT EK AND ZANNINI E. 2012. Fibre, protein and mineral fortification of wheat bread through milled and fermented brewer's spent grain enrichment. Eur Food Res Technol 235: 767778. 